\title{
KARAKTERISTIK MORFOLOGIS DAN GENETIS IKAN LELE AFRIKA (Clarias gariepinus Burchell, 1822) STRAIN MUTIARA
}

\author{
Bambang Iswanto ${ }^{\#}$, Rommy Suprapto, Huria Marnis, dan Imron
}

Balai Penelitian Pemuliaan Ikan

(Naskah diterima: 18 April 2015; Revisi final: 28 Agustus 2015, Disetujui publikasi: 2 September 2015)

\begin{abstract}
ABSTRAK
Ikan lele Mutiara merupakan strain baru ikan lele Afrika Clarias gariepinus hasil pemuliaan yang memiliki keunggulan karakteristik budidaya. Selain karakteristik budidayanya, karakteristik morfologis dan genetis ikan lele Mutiara juga perlu dibandingkan dengan strain yang lain. Penelitian ini bertujuan untuk menganalisis karakteristik morfologis ikan lele Mutiara (melalui uji morfometrik dan meristik), serta karakteristik genetis menggunakan marka DNA mikrosatelit dibandingkan dengan ikan lele Mesir, Paiton, Sangkuriang, dan Dumbo yang merupakan induk-induk pembentuknya. Karakterisasi morfometrik dilakukan melalui pengukuran terhadap 20 karakter, sedangkan karakterisasi meristik dilakukan melalui penghitungan terhadap lima karakter sesuai metode standar karakterisasi biometrik-morfologis ikan lele. Data karakteristik morfometrik dan meristik dievaluasi dengan menggunakan analisis komponen utama. Hasil karakterisasi morfologis menunjukkan bahwa karakteristik morfometrik dan meristik ikan lele Mutiara tidak dapat dibedakan dari ikan lele Mesir, Paiton, Sangkuriang, dan Dumbo. Karakterisasi secara genetis dengan menggunakan empat primer DNA mikrosatelit untuk ikan lele Afrika (Cga01, Cga02, Cga05, dan Cga09) menunjukkan bahwa ikan lele Mutiara memiliki keragaman genetis (jumlah alel dan heterozigositas) yang relatif lebih tinggi daripada ikan lele Mesir, Paiton, Sangkuriang, dan Dumbo.
\end{abstract}

KATA KUNCI: morfometrik, meristik, DNA mikrosatelit, ikan lele Afrika (Clarias gariepinus Burchell, 1822) strain Mutiara, Mesir, Paiton, Sangkuriang, dan Dumbo

ABSTRACT: Morphological and genetic characteristics of Mutiara strain of the African catfish (Clarias gariepinus Burchell, 1822)

Mutiara catfish is a new strain of the African catfish Clarias gariepinus resulted from a selective breeding program with superior characteristics in term of culture performances. Besides its superior culture perfomances, morphological characteristics of Mutiara catfish also need to be characterized in order to elucidate the differences compared to those of other cultured strains. The present study aimed to characterize the morphological characteristics of Mutiara catfish (through morphometric and meristic characterizations) and genetic characteristics using microsatellite DNA analysis compared to those of Mesir, Paiton, Sangkuriang, and Dumbo catfish as the founder populations. The morphometric characterization was carried out through measurement of 20 morphometric characters, while meristic characterization was carried out through the count of five meristic characters following the standard methods of biometricmorphological characterization of Clarias catfish. Morphometric and meristic data obtained were analyzed using principal component analysis. Morphological characterizations in the present study revealed that morphometric and meristic characteristics of Mutiara catfish could not be differentiated from those of Mesir, Paiton, Sangkuriang, and Dumbo catfish. Genetic characterization using four microsatellite DNA primers designed for African catfish (Cga01, Cga02, Cga05, and Cga09) suggested that genetic variation (alleles number and heterozygosity) of Mutiara catfish was higher than that of Mesir, Paiton, Sangkuriang, and Dumbo catfish.

KEYWORDS: $\quad$ morphometric, meristic, microsatellite DNA, Mutiara, Mesir, Paiton, Sangkuriang, and Dumbo strains of the African catfish (Clarias gariepinus Burchell, 1822)

\# Korespondensi: Balai Penelitian Pemuliaan Ikan.

Jl. Raya Sukamandi No. 2, Subang 41256, Indonesia.

Tel.: + (0260) 520500

E-mail: bambang.is031@kkp.go.id 


\section{PENDAHULUAN}

Ikan lele merupakan salah satu komoditas perikanan budidaya air tawar yang diunggulkan peningkatan produksinya oleh Kementerian Kelautan dan Perikanan. Upaya peningkatan produksi ikan lele nasional tersebut memerlukan peran kegiatan penelitian dan pengembangan, terutama melalui pemuliaan untuk menghasilkan strain baru ikan lele yang unggul. Pemuliaan ikan lele Afrika Clarias gariepinus (Burchell, 1822) telah dilakukan oleh Balai Penelitian Pemuliaan Ikan (BPPI) Sukamandi dan menghasilkan strain unggul baru, yakni ikan lele Mutiara.

Ikan lele Mutiara hingga saat ini merupakan satusatunya strain ikan lele Afrika unggul baru hasil pemuliaan di Indonesia yang dibentuk melalui program seleksi (selective breeding program). Strain-strain ikan lele Afrika yang lain di Indonesia merupakan ikan lele yang dibentuk melalui proses persilangan (crossbreeding ataupun backcross) ataupun hanya melalui proses introduksi. Ikan lele Mutiara dibentuk melalui seleksi individu pada karakter pertumbuhan selama tiga generasi. Seleksi individu selama tiga generasi tersebut telah menghasilkan respons seleksi kumulatif sebesar $52,64 \%$ berdasarkan parameter bobot. Selain itu, hasil pengujian keragaan-keragaan zooteknis menunjukkan bahwa ikan lele Mutiara memiliki keunggulan karakter yang relatif lengkap sebagai komoditas perikanan budidaya, terutama pada karakter pertumbuhan, efisiensi pakan, keseragaman ukuran, dan ketahanan terhadap penyakit, lingkungan, dan stres (BPPI, 2014).

Sebagai strain unggul yang baru, pengunaan ikan lele Mutiara dalam kegiatan budidaya ikan lele di lapangan tentunya akan sering bersamaan (berdampingan) dengan strain-strain ikan lele Afrika yang lain. Sebagai strain dari spesies yang sama, ada-tidaknya perbedaan ikan lele Mutiara dibandingkan dengan strain-strain ikan lele budidaya yang lain merupakan salah satu hal yang penting untuk diketahui. Ikan lele Mutiara dibentuk dari populasi dasar sintetis hasil gabungan persilangan dua arah (diallele cross) di antara populasi-populasi ikan lele Mesir, Paiton, Sangkuriang, dan Dumbo, sehingga terbentuk populasi komposit (Bambang et al., 2012). Oleh karena itu, perlu dilakukan penelitian karakterisasi untuk menemukan kemungkinan adanya penciri (penanda) khusus yang dapat membedakan ikan lele Mutiara dari strain-strain ikan lele Afrika yang lain. Penelitian ini dilakukan dengan tujuan untuk mempelajari karakteristik ikan lele Mutiara dibandingkan dengan ikan lele Mesir, Paiton, Sangkuriang, dan Dumbo sebagai populasi-populasi induk pembentuknya melalui karakterisasi secara morfologis pada karakterkarakter morfometrik dan meristik, serta secara ge- netis dengan menggunakan marka DNA mikrosatelit.

\section{BAHAN DAN METODE}

\section{Karakterisasi Morfologis}

Sampel ikan lele Mutiara yang digunakan merupakan ikan yang telah berukuran induk, sebanyak 34 ekor berukuran 1,8-2,2 kg (Gambar 1). Karakteristik biometrik-morfologis ikan lele Mutiara tersebut dibandingkan dengan ikan lele Mesir, Paiton, Sangkuriang, dan Dumbo sebagai populasi-populasi induk pembentuknya. Sampel ikan lele Mesir, Paiton, Sangkuriang, dan Dumbo yang digunakan secara berturut-turut berukuran 1,0-1,7 kg; 1,7-2,7 kg; 1,1-2,7 kg; dan 0,9-1,3 kg; masing-masing sebanyak 34 ekor, kecuali lele Dumbo sebanyak 18 ekor (Gambar 2). Seluruh sampel ikan lele Mesir, Paiton, Sangkuriang, dan Dumbo yang digunakan tersebut merupakan populasi-populasi induk yang digunakan dalam membentuk populasi dasar sintetis ikan lele Mutiara.

Karakterisasi morfologis sampel ikan lele Mutiara dan sampel ikan lele Mesir, Paiton, Sangkuriang, dan Dumbo pada penelitian ini dilakukan terhadap karakter morfometrik dan meristik pada spesimen yang hidup. Karakterisasi morfometrik dan meristik tersebut dilakukan berdasarkan metode standar yang umum digunakan dalam identifikasi spesies ikan lele Afrika (Agnese et al., 1997; Rognon et al., 1998; Teugels, 1998; Teugels et al., 1999a,b, 2007; Turan et al., 2005; Hanssens, 2009). Karakteristik meristik diidentifikasi melalui penghitungan terhadap jumlah jari-jari sirip dada, sirip perut, sirip punggung, dan sirip anal. Karakterisasi morfometrik dilakukan melalui pengukuran terhadap panjang standar, panjang

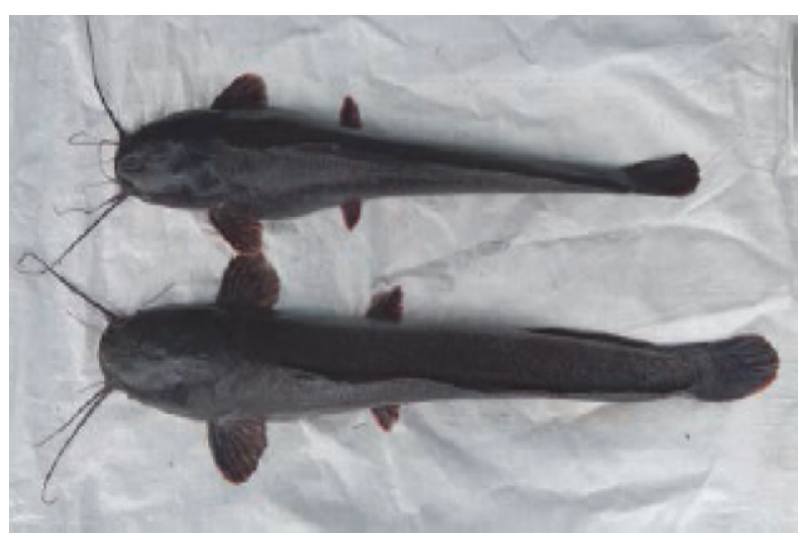

Gambar 1. Sampel ikan lele Afrika (Clarias gariepinus) strain Mutiara (Atas = Betina, Bawah = Jantan, Skala batang $=10 \mathrm{~cm}$ )

Figure 1. Samples of Mutiara strain of the African catfish Clarias gariepinus (Upper = Female, Lower $=$ Male, Bar scale $=10 \mathrm{~cm}$ ) 

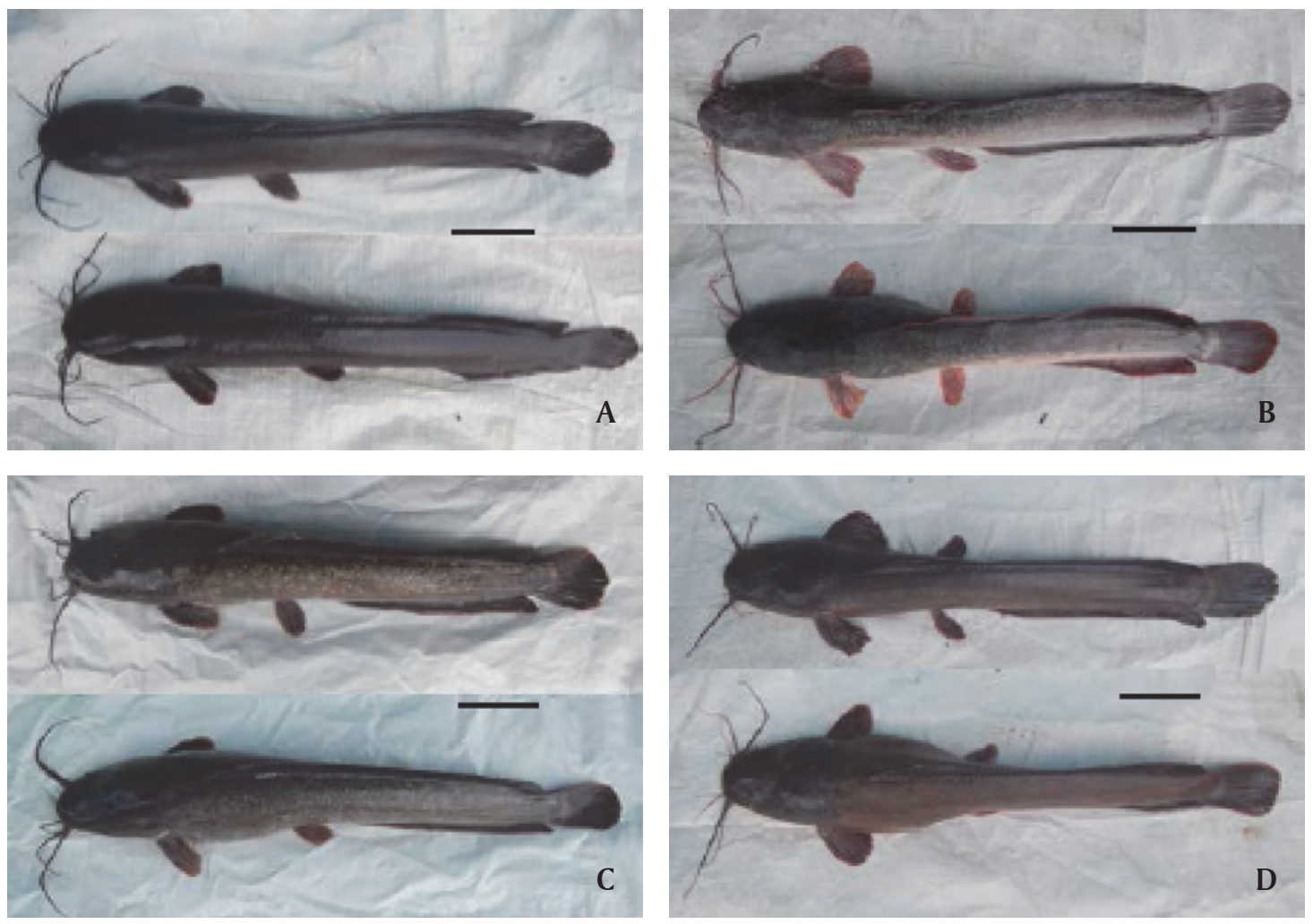

Gambar 2. Sampel ikan lele Afrika strain Mesir (A), Paiton (B), Sangkuriang (C), dan Dumbo (D) $($ Atas $=$ Betina, Bawah $=$ Jantan, Skala batang $=10 \mathrm{~cm})$

Figure 2. Samples of the African catfish strains: Mesir (A), Paiton (B), Sangkuriang (C), and Dumbo (D) $($ Upper $=$ Female, Lower $=$ Male, Bar scale $=10 \mathrm{~cm})$

kepala, lebar kepala, panjang moncong, jarak antar mata, diameter mata, panjang tonjolan oksipital, lebar tonjolan oksipital, jarak tonjolan oksipital ke sirip punggung, panjang predorsal, panjang prepektoral, panjang prepelvis, panjang preanal, panjang sirip anal, tinggi badan maksimum, tinggi batang ekor, lebar deretan gigi rahang atas, lebar deretan gigi rahang atas, lebar deretan gigi vomer, dan panjang deretan gigi vomer. Pengukuran karakter-karakter morfometrik tersebut dilakukan dengan menggunakan jangka sorong digital dengan tingkat ketelitian 0,01 mm (KRISBOW, China).

Data karakteristik morfometrik dan meristik yang diperoleh dianalisis sesuai metode analisis data morfometrik dan meristik yang umum digunakan dalam penelitian-penelitian karakterisasi biometrik ikan lele (Agnese et al., 1997; Rognon et al., 1998; Teugels, 1998; Teugels et al., 1999a,b; Sudarto, 2003; Pouyaud et al., 2009). Data karakter-karakter morfometrik dianalisis menggunakan analisis komponen utama (PCA $=$ principal component analysis) berdasarkan matriks kovarian. Data karakter-karakter morfometrik yang dianalisis tersebut sebelumnya ditransformasi secara logaritmis untuk meminimumkan pengaruh perbedaan ukuran ikan sampel. Komponen utama pertama (PC1) sebagai komponen utama yang berkaitan dengan faktor ukuran ikan (size factor) tidak digunakan dalam interpretasi hasil. Hanya komponen-komponen utama berikutnya sebagai komponen-komponen utama yang terkait dengan faktor bentuk (shape factors) yang digunakan dalam interpretasi hasil analisis data. Analisis komponen utama data karakterkarakter meristik juga dilakukan berdasarkan matriks kovarian terhadap data yang tidak ditransformasi. Selanjutnya, skor komponen utama dari masing-masing sampel diplot secara berpasangan di antara dua sumbu komponen utama dengan taraf kepercayaan elips (confidence ellips) 95\% untuk mengetahui bentuk sebaran masing-masing sampel ikan. Analisis data tersebut dilakukan dengan bantuan perangkat lunak komputer SYSTAT 11 (SYSTAT Software Inc., www. systat.com).

\section{Karakterisasi Genetis}

Karakterisasi genetis ikan lele Mutiara untuk menganalisis keragaman genetisnya dilakukan secara molekuler dengan marka DNA mikrosatelit. Karakterisasi DNA mikrosatelit tersebut dilakukan dengan menggunakan empat primer (lokus) yang khusus dikembangkan oleh Galbusera et al. (1996) untuk spesies ikan lele Afrika, yakni Cga01 (F: 5'-GGCTAAAA GAACCCTGTCTG-3', R: 5'-TACAGCGTCGATAAGCCA 
GG-3'), Cga02 (F: 5'-GCTAGTGTGAACGCAAGGC-3', R: 5'-ACCTCTGAGATAAAACACAGC-3'), Cga05 (F: 5'TCCACATTAAGGACAACCACCG-3', R: 5'-TTTGCAG TTCACGACTGCCG-3') dan Cga09 (F: 5'-CGTCCACTT CCCCTAGAGCG-3', R: 5'-CCAGCTGCATTACCATACAT GG-3'). Sampel ikan lele Mutiara yang digunakan dalam karakterisasi genetis ini sama dengan sampelsampel yang digunakan dalam karakterisasi morfologis. Karakteristik genetis ikan lele Mutiara tersebut dibandingkan dengan ikan lele Mesir, Paiton, Sangkuriang, dan Dumbo sebagai populasi-populasi induk pembentuknya.

DNA genom dari masing-masing sampel diekstraksi menggunakan paket ekstraksi Genejet ${ }^{\mathrm{TM}} \mathrm{Ge}$ nomic DNA Purification (Fermentas). Amplifikasi DNA genom hasil ekstraksi dilakukan dengan menggunakan MyCycler $^{\text {TM }}$ Thermal Cycler (BioRAD, USA) dengan siklus amplifikasi berupa inisiasi denaturasi pada suhu $94^{\circ} \mathrm{C}$ selama tiga menit, dilanjutkan masingmasing sebanyak 30 siklus denaturasi pada suhu $94^{\circ} \mathrm{C}$ selama 30 detik, annealing pada suhu yang direkomendasikan (masing-masing sesuai dengan jenis primer yang digunakan) selama 30 detik dan ekstensi pada suhu $72^{\circ} \mathrm{C}$ selama 30 detik, serta ekstensi akhir pada $72^{\circ} \mathrm{C}$ selama sepuluh menit. Pengecekan hasil amplifikasi PCR dilakukan dengan elektroforesis menggunakan gel agarose 1,5\%. Produk hasil amplifikasi selanjutnya dianalisis menggunakan QIAxcel Fragment Analyzer System (Qiagen, USA, www. qiagen.com) yang terintegrasi dengan program komputer Biocalculator (Qiagen, USA) dengan menggunakan catridge High Resolution kit (Qiagen, USA). Hasil pembacaan nilai alel pada program Biocalculator kemudian digunakan untuk estimasi parameterparameter keragaman genetis, antara lain: jumlah alel (A), heterozigositas teramati (Ho), heterozigositas harapan (He), dan indeks fiksasi dalam populasi (Fis) menggunakan program Fstat 2.9.3 (Goudet, 2001).

\section{HASIL DAN BAHASAN}

\section{Karakteristik Morfologis}

Hasil penghitungan karakter-karakter meristik dan pengukuran karakter-karakter morfometrik populasi ikan lele Mutiara dalam persentase terhadap panjang kepala (\%PK) dan panjang standar (\%PS) dibandingkan dengan induk-induk pembentuknya (ikan lele Mesir, Paiton, Sangkuriang, dan Dumbo) disajikan pada Tabel 1. Koefisien karakter-karakter morfometrik pada komponen utama kedua (PC2) dan ketiga (PC3) disajikan pada Tabel 2, sedangkan koefisien karakter-karakter meristik pada komponen utama pertama (PC1) dan kedua (PC2) disajikan pada Tabel 3. Diagram pencar hasil analisis komponen utama pada karakter morfometrik disajikan pada Gambar 3, sedangkan pada karakter meristik disajikan pada Gambar 4.

Hasil pengukuran karakter-karakter morfometrik dan penghitungan karakter-karakter meristik secara umum menunjukkan bahwa nilai-nilai karakter morfometrik dan meristik ikan lele Mutiara relatif sama dengan ikan lele Mesir, Paiton, Sangkuriang, dan Dumbo sebagai populasi-populasi induk pembentuknya. Nilai-nilai karakter morfometrik dan meristiknya dibandingkan dengan populasi-populasi induk pembentuknya tidak menunjukkan adanya perbedaan yang mencolok. Nilai-nilai karakter morfometrik dan meristik ikan lele Mutiara dan populasi-populasi induk pembentuknya tersebut juga tidak menunjukkan perbedaan yang mencolok dari nilai-nilai karakter morfometrik dan meristik ikan lele Afrika di perairan-perairan umum benua Afrika yang dilaporkan oleh Teugels (1986).

Diagram pencar pengeplotan skor sampel ikan lele Mutiara dan populasi-populasi induk pembentuknya pada sumbu komponen utama kedua (PC2) dan ketiga (PC3) hasil analisis komponen utama terhadap karakter-karakter morfometrik (Gambar 3) menunjukkan bahwa sebaran skor sampel ikan lele Mesir terpisah dari populasi-populasi ikan lele Paiton, Sangkuriang maupun Dumbo, sedangkan skor sampel ikan lele Mutiara berada di antara dan bersifat beririsan (overlap) dengan populasi-populasi induk pembentuknya tersebut. Hal tersebut mengindikasikan bahwa karakteristik morfometrik ikan lele Mesir berbeda dari populasi-populasi ikan lele Paiton, Sangkuriang, maupun Dumbo sebagai kelompok ikan lele Afrika yang memiliki karakteristik morfometrik serupa. Di antara keduanya, ikan lele Mutiara memiliki karakteristik morfometrik yang tidak dapat dibedakan dari ikan lele Mesir maupun populasi ikan lele Paiton, Sangkuriang, dan Dumbo. Tidak berbedanya karakteristik morfometrik ikan lele Mutiara dibandingkan dengan populasi-populasi induk pembentuknya tersebut merupakan hal yang wajar, karena ikan lele Mutiara merupakan ikan lele Afrika $C$. gariepinus yang dibentuk dari populasi komposit hasil gabungan dari persilangan dua arah di antara populasi-populasi ikan lele Mesir, Paiton, Sangkuriang, dan Dumbo (Bambang et al., 2012). Sifat khas karakteristik morfometrik ikan lele Mesir yang berbeda dari populasi-populasi ikan lele Afrika yang lain tersebut juga dilaporkan untuk strain-strain ikan lele Afrika di Benua Afrika (Rognon et al., 1998; Teugels, 1998). Karakter-karakter morfometrik yang berperan dalam membedakan karakteristik ikan lele Mesir dari ikan lele Dumbo, Sangkuriang dan Paiton tersebut terutama adalah (Tabel 2) jarak tonjolan oksipital ke 
Tabel 1. Karakteristik morfometrik ddalam persentase terhadap panjang standar (\% PS) dan panjang kepala $(\% \mathrm{PK})\}$ dan meristik ikan lele Afrika strain Mutiara dibandingkan dengan strain Mesir, Paiton, Sangkuriang, dan Dumbo sebagai populasi-populasi induk pembentuknya

Table 1. Morphometric in the percentage of standard length $(\% \mathrm{SL})$ and head length $(\% \mathrm{HL})\}$ and meristic characteristics of Mutiara strain of the African catfish compared to those of Mesir, Paiton, Sangkuriang, dan Dumbo strains as the founder populations

\begin{tabular}{|c|c|c|c|c|c|}
\hline \multirow{2}{*}{ Karakter (Characters) } & \multicolumn{5}{|c|}{ Strain (Strains) } \\
\hline & Mutiara & Dumbo & Sangkuriang & Paiton & Mesir \\
\hline $\begin{array}{l}\text { Panjang kepala }(\% \mathrm{PS}) \\
\text { Head length }(\% S L)\end{array}$ & $24.33-30.59$ & $23.68-28.78$ & $26.36-30.27$ & $25.00-30.63$ & $23.29-27.60$ \\
\hline $\begin{array}{l}\text { Lebar kepala (\% PS) } \\
\text { Head width (\% SL) }\end{array}$ & $14.87-20.06$ & $15.91-19.32$ & $16.58-19.93$ & $16.11-19.34$ & $15.13-17.61$ \\
\hline $\begin{array}{l}\text { Panjang moncong }(\% \mathrm{PK}) \\
\text { Snout length }(\% \mathrm{HL})\end{array}$ & $18.00-24.38$ & $18.31-23.88$ & $18.59-25.29$ & $17.41-26.10$ & $17.84-26.89$ \\
\hline $\begin{array}{l}\text { Jarak antar mata }(\% \mathrm{PK}) \\
\text { Interorbital width }(\% \mathrm{HL})\end{array}$ & $39.03-44.17$ & $37.51-42.85$ & $37.47-43.36$ & $37.85-42.80$ & $38.61-45.52$ \\
\hline $\begin{array}{l}\text { Diameter mata }(\% \mathrm{PK}) \\
\text { Eye diameter }(\% \mathrm{HL})\end{array}$ & 5.01-6.55 & $5.77-7.15$ & $5.26-8.25$ & $5.44-7.88$ & $4.46-5.94$ \\
\hline $\begin{array}{l}\text { Panjang tonjolan oksipital (\% PK) } \\
\text { Occipital process length }(\% \mathrm{HL})\end{array}$ & $10.69-19.49$ & $11.30-16.30$ & $12.07-19.77$ & $11.30-16.30$ & $12.56-19.84$ \\
\hline $\begin{array}{l}\text { Lebar tonjolan oksipital }(\% \mathrm{PK}) \\
\text { Occipital process width }(\% \mathrm{HL})\end{array}$ & $17.89-23.91$ & $16.46-23.79$ & $15.67-21.47$ & $15.73-22.39$ & $20.04-25.13$ \\
\hline $\begin{array}{l}\text { Jarak tonjolan oksipital ke sirip pung- } \\
\text { gung }(\% \mathrm{PS})(\text { Occipital process to dorsal fin } \\
\text { distance }(\% \text { SL)) }\end{array}$ & $3.54-6.37$ & $2.67-5.64$ & $4.62-6.74$ & $3.36-5.70$ & $5.61-7.74$ \\
\hline $\begin{array}{l}\text { Panjang predorsal }(\% \text { PS) } \\
\text { Predorsal length }(\% S L)\end{array}$ & $28.31-35.93$ & $27.74-33.76$ & $31.71-36.80$ & $28.91-35.65$ & $28.74-33.75$ \\
\hline $\begin{array}{l}\text { Panjang sirip punggung }(\% \text { PS) } \\
\text { Dorsal fin length }(\% S L)\end{array}$ & 63.58-73.79 & $63.62-68.17$ & $62.37-68.71$ & $62.83-70.07$ & $63.73-68.82$ \\
\hline $\begin{array}{l}\text { Panjang prepektoral (\% PS) } \\
\text { Prepectoral length (\% SL) }\end{array}$ & $15.67-21.93$ & $17.81-20.77$ & $17.17-22.68$ & $17.71-21.33$ & $16.28-18.97$ \\
\hline $\begin{array}{l}\text { Panjang prepelvis }(\% \mathrm{PS}) \\
\text { Prepelvic length }(\% S L)\end{array}$ & $39.55-46.65$ & $39.21-45.50$ & $42.60-47.91$ & $40.03-45.91$ & $39.36-44.50$ \\
\hline $\begin{array}{l}\text { Panjang preanal }(\% \mathrm{PS}) \\
\text { Preanal length }(\% S L)\end{array}$ & $48.36-58.18$ & $47.54-54.31$ & $50.45-56.87$ & $48.61-56.91$ & $49.84-55.56$ \\
\hline $\begin{array}{l}\text { Panjang sirip anal }(\% \mathrm{PS}) \\
\text { Anal fin length }(\% \mathrm{SL})\end{array}$ & $40.15-48.33$ & $41.27-47.64$ & $41.50-46.71$ & $40.00-46.58$ & $40.85-46.89$ \\
\hline $\begin{array}{l}\text { Tinggi badan maksimum (\% PS) } \\
\text { Maximum body depth (\% SL) }\end{array}$ & $11.63-17.43$ & $10.46-15.45$ & $12.41-16.68$ & $9.22-14.17$ & $10.35-13.81$ \\
\hline $\begin{array}{l}\text { Tinggi batang ekor (\% PS) } \\
\text { Caudal peduncle depth }(\% \text { SL) }\end{array}$ & $6.19-8.70$ & $6.20-8.56$ & $6.24-8.97$ & $6.13-7.95$ & $5.67-7.24$ \\
\hline $\begin{array}{l}\text { Lebar deretan gigi rahang atas }(\% \mathrm{PK}) \\
\text { Premaxillary toothplate width }(\% \mathrm{HL})\end{array}$ & $23.66-33.01$ & $23.88-29.50$ & $23.71-28.03$ & $22.20-28.59$ & $21.72-27.47$ \\
\hline $\begin{array}{l}\text { Lebar deretan gigi vomer }(\% \mathrm{PK}) \\
\text { Vomerine toothplate width }(\% \mathrm{HL})\end{array}$ & $19.39-25.08$ & $21.95-26.26$ & $19.14-24.92$ & $21.77-25.61$ & $17.49-24.22$ \\
\hline $\begin{array}{l}\text { Panjang deretan gigi rahang atas (\% PK) } \\
\text { Premaxillary toothplate length }(\% \mathrm{HL})\end{array}$ & $3.38-5.28$ & $3.15-5.56$ & $3.08-5.29$ & $2.48-5.04$ & $3.76-6.01$ \\
\hline
\end{tabular}


Lanjutan Tabel 1 (Table 1 continued)

\begin{tabular}{|c|c|c|c|c|c|}
\hline \multirow{2}{*}{ Karakter (Characters) } & \multicolumn{5}{|c|}{ Strain (Strains) } \\
\hline & Mutiara & Dumbo & Sangkuriang & Paiton & Mesir \\
\hline $\begin{array}{l}\text { Panjang deretan gigi vomer }(\% \mathrm{PK}) \\
\text { Vomerine toothplate length }(\% \mathrm{HL})\end{array}$ & $4.63-8.79$ & $2.64-6.02$ & $3.25-6.31$ & $3.55-7.12$ & $4.46-8.71$ \\
\hline $\begin{array}{l}\text { Jumlah jari-jari sirip punggung } \\
\text { Dorsal fin rays number }\end{array}$ & $64-75$ & $63-75$ & $61-76$ & $65-74$ & $63-71$ \\
\hline $\begin{array}{l}\text { Jumlah jari-jari sirip dada } \\
\text { Pectoral fin rays number }\end{array}$ & $9-11$ & $9-11$ & $9-11$ & $9-11$ & $9-11$ \\
\hline $\begin{array}{l}\text { Jumlah jari-jari sirip perut } \\
\text { Pelvic fin rays number }\end{array}$ & $5-6$ & $5-6$ & $5-6$ & $5-6$ & $5-6$ \\
\hline $\begin{array}{l}\text { Jumlah jari-jari sirip anal } \\
\text { Anal fin rays number }\end{array}$ & $47-59$ & $46-57$ & $45-55$ & $48-56$ & $46-55$ \\
\hline
\end{tabular}

Tabel 2. Koefisien masing-masing karakter morfometrik pada komponen utama kedua (PC2) dan ketiga (PC3) hasil analisis komponen utama terhadap sampel ikan lele Afrika strain Mutiara, Mesir, Paiton, Sangkuriang, dan Dumbo

Table 2. Coefficients of each morphometric character on the second (PC2) and third (PC3) principal component resulted from a principal component analysis (PCA) performed on the samples of Mutiara, Mesir, Paiton, Sangkuriang, and Dumbo strains of the African catfish

\begin{tabular}{lcc}
\hline \multicolumn{1}{c}{ Karakter morfometrik } & Porphometric characters & PC3 \\
\hline Panjang kepala (Head length) & -0.1869 & -0.0360 \\
Lebar kepala (Head width) & -0.1889 & -0.0679 \\
Panjang moncong (Snout length) & -0.2407 & -0.0526 \\
Jarak antar mata (Interorbital width) & -0.0520 & -0.0396 \\
Diameter mata (Eye diameter) & -0.6202 & 0.0891 \\
Panjang tonjolan oksipital (Occipital process length) & -0.0125 & -0.0759 \\
Lebar tonjolan oksipital (Occipital process width) & -0.2324 & -0.1646 \\
Jarak tonjolan oksipital ke sirip punggung & & \\
Occipital process to dorsal fin distance & 0.7702 & -0.4454 \\
Panjang predorsal (Predorsal length) & & \\
Panjang sirip punggung (Dorsal fin length) & 0.0134 & -0.1410 \\
Panjang prepektoral (Prepectoral length) & 0.0361 & -0.0946 \\
Panjang prepelvis (Prepelvic length) & -0.2283 & -0.0486 \\
Panjang preanal (Preanal length) & 0.0235 & -0.1552 \\
Panjang sirip anal (Anal fin length) & 0.0623 & -0.1912 \\
Tinggi badan maksimum (Maximum body depth) & 0.0134 & -0.0500 \\
Tinggi batang ekor (Caudal peduncle depth) & 0.2206 & -0.1219 \\
Lebar deretan gigi rahang atas (Premaxillary toothplate width) & -0.1529 & 0.1311 \\
Lebar deretan gigi vomer (Vomerine toothplate width) & -0.2784 & 0.1220 \\
Panjang deretan gigi rahang atas (Premaxillary toothplate length) & -0.3135 & 0.0830 \\
Panjang deretan gigi vomer (Vomerine toothplate length) & 0.0682 & 0.1567 \\
Jumlah jari-jari sirip punggung (Dorsal fin rays number) & 0.5526 & 0.4298 \\
Jumlah jari-jari sirip dada (Pectoral fin rays number) & -0.1869 & -0.0360 \\
Jumlah jari-jari sirip perut (Pelvic fin rays number) & -0.1889 & -0.0679 \\
Jumlah jari-jari sirip anal (Anal fin rays number) & -0.2407 & -0.0526 \\
\hline & -0.0520 & -0.0396 \\
\hline
\end{tabular}


Tabel 3. Koefisien masing-masing karakter meristik pada komponen utama pertama (PC1) dan kedua (PC2) hasil analisis komponen utama terhadap sampel ikan lele Afrika strain Mutiara, Mesir, Paiton, Sangkuriang, dan Dumbo

Table 3. Coefficients of each morphometric character on the first (PC1) and second (PC2) principal components resulted from a principal component analysis (PCA) performed on the samples of Mutiara, Mesir, Paiton, Sangkuriang, and Dumbo strains of the African catfish

\begin{tabular}{lcc}
\hline \multicolumn{1}{c}{ Karakter meristik (Meristic characters) } & PC1 & PC2 \\
\hline Jumlah jari-jari sirip punggung (Dorsal fin rays number) & 0.9365 & -0.3507 \\
Jumlah jari-jari sirip dada (Pectoral fin rays number) & 0.0701 & -0.0262 \\
Jumlah jari-jari sirip perut (Pelvic fin rays number) & -0.0557 & 0.0344 \\
Jumlah jari-jari sirip anal (Anal fin rays number) & 0.7427 & 0.6696 \\
\hline
\end{tabular}

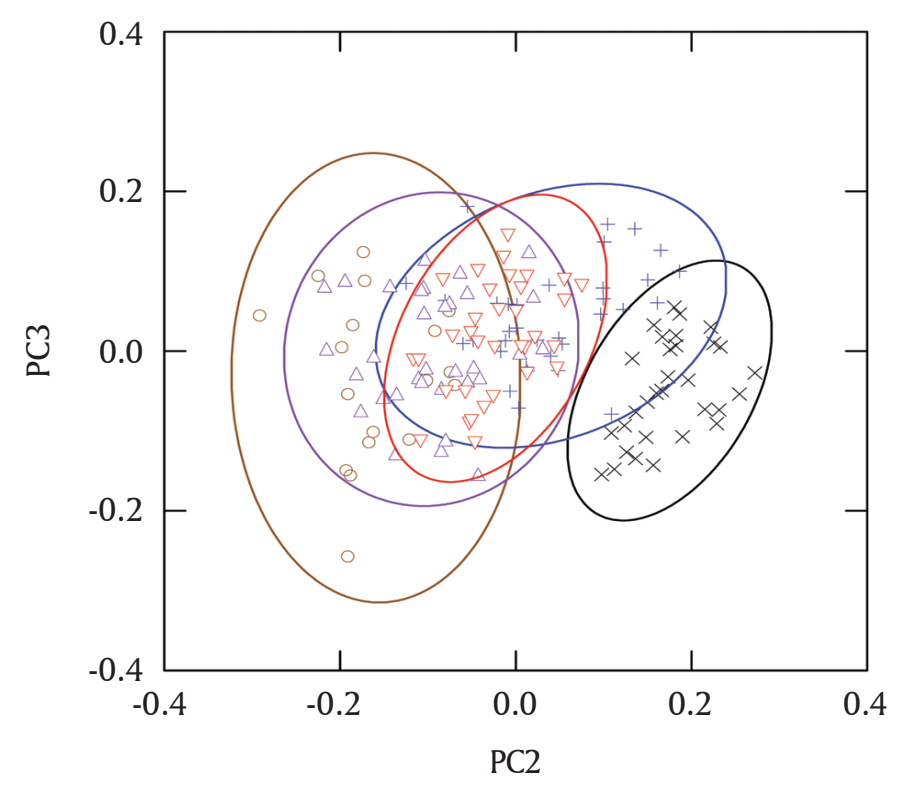

Gambar 3. Diagram pencar skor sampel-sampel ikan lele Afrika strain Mutiara $(+)$ dibandingkan dengan ikan strain Mesir (x), Paiton (W), Sangkuriang (X), dan Dumbo (o) sebagai populasi-populasi induk pembentuknya pada sumbu komponen utama kedua (PC2) dan ketiga (PC3) hasil analisis komponen utama (PCA) terhadap karakter-karakter morfometrik

Figure 3. A scatter plot of the scores of Mutiara (+) strain of the African catfish compared to those of Mesir $(\mathrm{x})$, Paiton (W), Sangkuriang (X), and Dumbo (o) strains as the founder populations along the second (PC2) and third (PC3) axes resulted from a principal component analysis (PCA) for the morphometric characters

sirip punggung, diameter mata, dan lebar deretan gigi vomer (lihat Tabel 1).

Diagram pencar hasil analisis komponen utama terhadap karakter-karakter meristik pada penelitian ini (Gambar 4) menunjukkan bahwa skor dari ikan lele Mutiara dan seluruh populasi-populasi induk pembentukannya bersifat saling beririsan. Hal tersebut mengindikasikan bahwa karakteristik meristik ikan lele Mutiara tidak berbeda dari populasi-populasi induk pembentuknya, sehingga tidak ada karakter meristik yang dapat digunakan sebagai karakter diagnosis untuk membedakan ikan lele Mutiara dari populasi-populasi induk pembentuknya.

\section{Karakteristik Genetis}

Primer Cga01, Cga02, Cga05, dan Cga09 yang digunakan dalam karakterisasi keragaman genetis ikan lele Mutiara, Mesir, Paiton, Sangkuriang, dan Dumbo pada penelitian ini bersifat polimorfis, dengan nilai PIC (polymorphic information content) berkisar 0,460,78 . Primer-primer tersebut bersama dengan primer-primer lain yang didesain untuk analisis DNA mikrosatelit ikan lele Afrika telah digunakan dalam penelitian karakterisasi genetis ikan lele Afrika di Belgia (Galbusera et al., 1996; Volckaert \& Hellemans, 1999), dari Senegal (Agnese et al., 1997), dari Zambia (Volckaert et al., 1999), di Thailand (Wachirachaikarn 


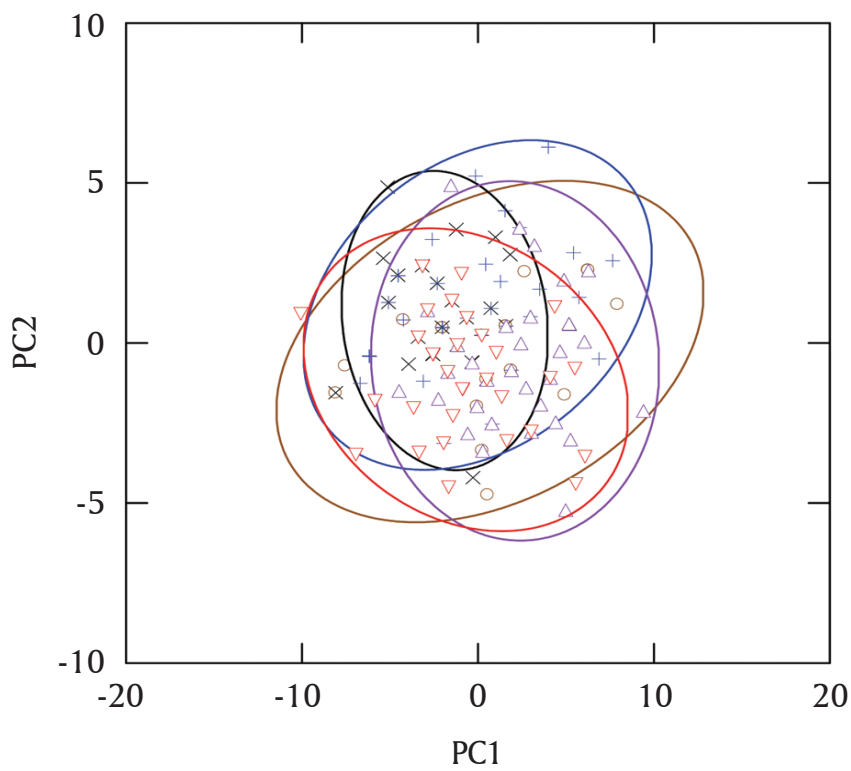

Gambar 4. Diagram pencar skor sampel-sampel ikan lele Afrika strain Mutiara (+) dibandingkan dengan ikan strain Mesir (x), Paiton (W), Sangkuriang (X), dan Dumbo (o) sebagai populasi-populasi induk pembentuknya pada sumbu komponen utama pertama (PC1) dan kedua (PC2) hasil analisis komponen utama (PCA) terhadap karakter-karakter meristik

Figure 4. A scatter plot of the scores of Mutiara (+) strain of the African catfish compared to those of Mesir $(x)$, Paiton (W), Sangkuriang (X), and Dumbo (o) strains as the founder populations along the first (PC1) and second (PC2) axes resulted from a principal component analysis (PCA) for the meristic characters

et al., 2009), dan di Nigeria (Agbebi et al., 2013). Hasil karakterisasi genetis ikan lele Mutiara dibandingkan dengan ikan lele Mesir, Paiton, Sangkuriang, dan Dumbo sebagai populasi-populasi induk pembentuknya pada parameter jumlah alel, heterozigositas, dan indeks fiksasi menggunakan primer Cga01, Cga02, Cga05, dan Cga09 disajikan pada Tabel 4.

Ukuran fragmen DNA sampel ikan lele Mutiara, Mesir, Paiton, Sangkuriang, dan Dumbo hasil ampli- fikasi dengan menggunakan primer $\mathrm{Cga01}, \mathrm{Cga02}$, $\mathrm{Cga05}$, dan $\mathrm{Cga09}$ menunjukkan pola yang relatif serupa, sehingga tampaknya tidak dapat digunakan sebagai marka (penanda) spesifik untuk membedakan strain-strain ikan lele tersebut. Hasil amplifikasi sampel ikan lele Mutiara, Mesir, Paiton, Sangkuriang, dan Dumbo menggunakan primer Cga01 menghasilkan fragmen-fragmen DNA berukuran 132-158 bp, primer Cga02 menghasilkan fragmen-fragmen DNA berukuran 102-124 bp, primer Cga05 menghasilkan

Tabel 4. Karakteristik keragaman genetis ikan lele Afrika strain Mutiara, Mesir, Paiton, Sangkuriang, dan Dumbo berdasarkan analisis DNA mikrosatelit menggunakan primer Cga01, Cga02, Cga05, dan Cga09

Table 4. Genetic parameters of Mutiara, Mesir, Paiton, Sangkuriang, and Dumbo strains of the African catfish based on microsatellite DNA analysis using Cga01, Cga02, Cga05, and Cga09 primers

\begin{tabular}{|c|c|c|c|c|c|}
\hline \multirow{2}{*}{$\begin{array}{l}\text { Parameter } \\
\text { Parameters }\end{array}$} & \multicolumn{5}{|c|}{ Strain (Strains) } \\
\hline & Mutiara & Dumbo & Sangkuriang & Paiton & Mesir \\
\hline Jumlah alel (Alleles number) & 12.75 & 6.75 & 8.00 & 8.25 & 5.75 \\
\hline $\begin{array}{l}\text { Heterozigositas harapan } \\
\text { Expected heterozygosity }\end{array}$ & 0.86 & 0.77 & 0.8 & 0.78 & 0.72 \\
\hline $\begin{array}{l}\text { Heterozigositas teramati } \\
\text { Observed heterozygosity }\end{array}$ & 0.50 & 0.47 & 0.57 & 0.49 & 0.47 \\
\hline Indeks fiksasi (Fixation index) & 0.42 & 0.42 & 0.32 & 0.39 & 0.34 \\
\hline
\end{tabular}


fragmen-fragmen DNA berukuran 226-248 bp, dan primer Cga09 menghasilkan fragmen-fragmen DNA berukuran 210-246 bp. Ukuran fragmen-fragmen DNA ikan lele Mutiara, Mesir, Paiton, Sangkuriang, dan Dumbo tersebut menunjukkan nilai yang relatif berbeda dari hasil penelitian Galbusera et al. (1996), Volckaert \& Hellemans (1999), dan Volckaert et al. (1999). Secara umum, ukuran fragmen DNA ikan lele Mutiara, Mesir, Paiton, Sangkuriang, dan Dumbo pada penelitian ini memiliki ukuran yang relatif lebih besar. Hal tersebut mungkin dikarenakan perbedaan strain yang digunakan.

Seluruh strain ikan lele yang digunakan dalam penelitian ini secara umum tidak menunjukkan dalam kondisi keseimbangan Hardy-Weinberg dan cenderung mengalami defisit heterozigositas, serta menunjukkan tingkat fiksasi alel yang relatif tinggi. Pada ikan lele Mesir, Paiton, Sangkuriang, dan Dumbo sebagai strain-strain yang telah lama digunakan dalam kegiatan budidaya hal tersebut mengindikasikan adanya kemungkinan bahwa strain-strain tersebut telah mengalami tingkat perkawinan dalam (inbreeding) yang relatif tinggi, sedangkan pada ikan lele Mutiara yang merupakan strain baru hal tersebut kemungkinan merupakan akibat dari proses seleksi yang dilakukan sehingga meningkatkan fiksasi alel-alel tertentu. Kondisi defisit heterozigositas juga dilaporkan terjadi pada populasi-populasi ikan lele Afrika dari perairan Senegal (Agnese et al., 1997), ikan lele Afrika yang digunakan dalam kegiatan pemuliaan melalui seleksi individu dan famili di Belgia (Volckaert \& Hellemans, 1999) dan hibridisasi di Thailand (Wachirachaikarn et al., 2009), serta ikan lele Afrika yang dibudidayakan di Nigeria (Agbebi et al., 2013).

Berdasarkan parameter jumlah alel, ikan lele Mesir, Paiton, Sangkuriang, dan Dumbo memiliki nilai yang relatif sama (berkisar 3-11 alel), sedangkan ikan lele Mutiara memiliki jumlah alel yang lebih banyak (berkisar 7-18 alel). Hal tersebut mengindikasikan bahwa keragaman genetis ikan lele Mutiara relatif lebih tinggi daripada ikan lele Mesir, Paiton, Sangkuriang, dan Dumbo. Ikan lele Afrika yang berasal dari Zambia (Volckaert et al., 1999) dan Nigeria (Agbebi et al., 2013), serta yang dibudidayakan di Belgia (Galbusera et al., 1996; Volckaert \& Hellemans, 1999) dan Thailand (Wachirachaikarn et al., 2009) memiliki jumlah alel yang relatif sama dengan ikan lele Mesir, Paiton, Sangkuriang, dan Dumbo.

\section{KESIMPULAN}

Karakteristik morfometrik dan meristik ikan lele Mutiara tidak dapat dibedakan dari ikan lele Mesir, Paiton, Sangkuriang, dan Dumbo sebagai populasipopulasi induk pembentuknya. Secara genetis, ikan lele Mutiara memiliki keragaman genetis (jumlah alel dan heterozigositas) yang relatif lebih tinggi daripada ikan lele Mesir, Paiton, Sangkuriang, dan Dumbo.

\section{UCAPAN TERIMA KASIH}

Penulis menyampaikan terima kasih yang sebesar-besarnya kepada para pembantu peneliti komoditas penelitian ikan lele BPPI Sukamandi atas bantuan teknisnya selama penyiapan sampel.

\section{DAFTAR ACUAN}

Agbebi, O.T., Ilaboya, D.E., \& Adebambo, A.O. (2013). Preliminary characterization of genetic strains in Clariid species, Clarias gariepinus and Heterobranchus bidorsalis using microsatellite markers. African Journal of Biotechnology, 12(4), 364-369.

Agnese, J.F., Teugels, G.G., Galbusera, P., Guyomard, R., \& Volckaert, F. (1997). Morphometric and genetic characterization of sympatric populations of Clarias gariepinus and C. anguillaris from Senegal. Journal of Fish Biology, 50, 1143-1157.

Bambang, I., Suprapto, R., Marnis, H., \& Imron. (2012). Perakitan strain ikan lele Clarias gariepinus (Burchell, 1822) cepat tumbuh melalui seleksi individu: pembentukan populasi dasar sintetis. Prosiding Forum Inovasi Teknologi Akuakultur 2012. hlm. 1197-1210.

BPPI. (2014). Naskah Akademis Permohonan Pelepasan Ikan Lele Tumbuh Cepat Generasi Ketiga Hasil Seleksi Individu. Balai Penelitian Pemuliaan Ikan. Sukamandi. $86 \mathrm{hlm}$.

Galbusera, P., Volckaert, F., Hellemans, B., \& Ollevier, F. (1996). Isolation and characterisation of microsatellite markers in the African catfish Clarias gariepinus Burchell, 1822. Molecular Ecology, 5, 703705.

Goudet, J. (2001). FSTAT, a program to estimate and test gene diversities and fixation indices (version 2.9.3). Diunduh dari: http://www2.unil.ch/izea/ softwares/fstat.html.

Hanssens, M. (2009). A review of the Clarias species (Pisces; Siluriformes) from the Lower Congo and the Pool Malebo. Journal of Afrotropical Zoology, 5, 27-40.

Pouyaud, L., Sudarto, \& Paradis, E. (2009). The phylogenetic structure of habitat shift and morphological convergence in Asian Clarias (Teleostei, Siluriformes: Clariidae). Journal of Zoological Systematics and Evolutionary Research, 47(4), 344-356.

Rognon, X., Teugels, G.G., Guyomard, R., Galbusera, P., Andriamanga, M., Volkcaert, F., \& Agnese, J. F. (1998). Morphometric and allozyme variation in the African catfishes Clarias gariepinus and $C$. anguillaris. Journal of Fish Biology, 53, 192-207. 
Sudarto. (2003). Systematic revision and phylogenetic relationships among populations of Clariid species in Southeast Asia. Doctoral Dissertation. University of Indonesia. Depok, 263 pp.

Teugels, G.G. (1986). A systematic revision of the African species of the genus Clarias (Pisces: Clariidae). Annales Musee Royal de l'Afrique Centrale, 247, 1-199.

Teugels, G.G. (1998). Intra- and interspecific morphometric variation in Clarias gariepinus and $C$. anguillaris (Siluroidei, Clariidae). Genetics and Aquaculture in Africa. Actes du colloque Génétique et aquaculture en Afrique, Abidjan, $1^{\mathrm{er}}-4$ avril 1997. Agnese, J.F. (Ed.). Institut Francais de Recherche Scientifique pour le Developpement en Cooperation, Paris. France, p. 241-248.

Teugels, G.G., Adriaens, D., Devaere, S., \& Musschoot, T. (2007). Clariidae. The Fresh and Brackish Water Fishes of Lower Guinea, West-Central Africa Volume I. Stiassny, M.L.J., Teugels, G.G., \& Hopkins, C.D. (Eds.). IRD-MNHN-MRAC. Paris, p. 653-691.

Teugels, G.G., Legendre, M., \& Hung, L.T. (1999a). Preliminary results on the morphological characterisation of natural population and cultured strains of Clarias species (Siluriformes, Clariidae) from Vietnam. Proceeding of The Mid-Term Workshop of the Catfish Asia Project, 11-15 May 1998, Cantho, Vietnam. Legendre, M., \& Parisele, A. (Eds.). The Biological Diversity and Aquaculture of Clariid and Pangasiid Catfishes in South-East Asia. p. 27-30.
Teugels, G.G., Gustiano, R., Diego, R., Legendre, M., \& Sudarto. (1999b). Preliminary results on the morphological characterisation of natural population and cultured strains of Clarias species (Siluriformes, Clariidae) from Indonesia. Proceeding of The Mid-Term Workshop of the Catfish Asia Project, 11-15 May 1998, Cantho, Vietnam. Legendre, M., \& Parisele, A. (Eds.). The Biological Diversity and Aquaculture of Clariid and Pangasiid Catfishes in South-East Asia. p. 31-36.

Turan, C., Yalcin, S., Turan, F., Okur, E., \& Akyurt, I. (2005). Morphometric comparisons of African catfish, Clarias gariepinus, in Turkey. Foolia Zoologica, 54(1-2), 165-172.

Volkcaert, F.A.M., \& Hellemans, B. (1999). Survival, growth and selection in a communally reared multifactorial cross of African catfish (Clarias gariepinus). Aquaculture, 171, 49-64.

Volckaert, F., Hellemans, B., \& Pouyaud, L. (1999). Preliminary data on genetic variation in the genus Clarias and Pangasius on the basis of DNA microsatellite loci. Proceeding of The Mid-Term Workshop of the Catfish Asia Project, 11-15 May 1998, Cantho, Vietnam. Legendre,M., \& Parisele, A. (Eds.). The Biological Diversity and Aquaculture of Clariid and Pangasiid Catfishes in South-East Asia. p. 57-60.

Wachirachaikarn, A., Rungsin, W., Srisapoome, P., \& Na-Nakorn, U. (2009). Crossing of African catfish, Clarias gariepinus (Burchell, 1822), strains based on strain selection using genetic diversity data. Aquaculture, 290, 53-60. 